\title{
The Pentahelix Stakeholders Analysis on Tourism Development in Tanjungpinang
}

\author{
Nina Widowati ${ }^{1}$, Endang Larasati ${ }^{2}$ \\ \{ninawidowati.fisip@gmail.com ${ }^{1}$ \} \\ Universitas Diponegoro, Indonesia ${ }^{1,2}$
}

\begin{abstract}
Development of tourism is closely connected with the involvement of stakeholders. This study aims to identify the stakeholders involved, analyze the roles of the stakeholders involved, and analyze the inhibiting aspects. The role of stakeholders in realizing tourist destination goals optimally and realizing sustainable tourism. Tanjungpinang is a tourist destination in the Riau Islands Province. The less optimal role of relevant stakeholders in tourism development cooperation has made the Tanjungpinang tourist destination not experiencing a significant increase. The study used a qualitative descriptive approach, with data collection techniques combining online interviews and documentation. From this research, it is found that the development of Tanjungpinang tourism destination involves stakeholders from academia, business, community, government and mass media, which means using the Pentahelix concept in its development. There are 38 stakeholders involved with the roles of stakeholders which are carried out in accordance with their respective main duties and functions. The role of local higher education academics is still not optimal in tourism development in Tanjungpinang. Aspects of trust and policy are the inhibiting aspects of Tanjungpinang tourism development.
\end{abstract}

Keywords: Tourism, Stakeholder Identification, Stakeholder Role, Tanjungpinang

\section{Introduction}

Geographically, each region will have different potentials, so the treatment and development style also need to be differentiated between regions. As an adaptive sector in various circumstances-meaning that any condition and anywhere can become a potential for tourism depending on the intelligence to capture market tastes and the professionalism of its management. The building of strong relationships through the active participation of all stakeholder with equal positions will form a high commitment and provide mutual stimulus for tourism development. According to Sun Aryo in Nugroho et al. [1] the performance of national tourism is still not optimal due to the general problem of managing the tourism system itself, one of which is that the partnership between the government and the private sector has not been optimal.

Riau Islands Province is one of the tourist destinations in Indonesia which has tourism objects that are potential enough to be developed. With the implementation of regional autonomy by the central government in early 1998, the Riau Islands provincial government was increasingly active in developing various sectors, including the tourism sector. According to the Public Relations of the Tanjungpinang Government, during February 2018, 4,810 
tourists from China entered Tanjungpinang via Raja Haji Fisabilillah Airport, this is a big opportunity that must be caught.

The results of Susanti's research [2] show that the strategy adopted by the Tanjungpinang City Tourism Office is still lacking and the lack of local government attention to Tanjungpinang City tourism, this is seen from the indicators in strategic planning, namely there are still many work programs that have not been implemented, the limited budget for tourism development, the low quality of human resources in tourism management. The suggestion from this research is that the government, especially the Department of Culture and Tourism, must re-evaluate the management and development of tourism in Tanjungpinang City, increase cooperation in the tourism sector with related parties and improve the accessibility of Tanjungpinang City tourism. Thus, it can be assumed to be still found indications of problems in carrier city tourism Tanjungpinang relating to cooperation/partnership between the actors involved. To make Tanjungpinang a tourist destination requires commitment and support from various stakeholders.

From the background of the problems above, it can be assumed that the problems faced by Tanjungpinang City in tourism development, among others, are related to the role of actors/stakeholders in partnerships between stakeholders or tourism business actors that have not been maximized. So, the research question that will be answered in this study is why the role of actors in partnership with tourism business actors in the city of Tanjungpinang has not been maximized. Based on the above background, the tittle of this research is: "The Role of Stakeholders in Tourism Development in Tanjungpinang". Starting from the background of this research, the formulation of the problem can be stated as follows:

a) Who are the stakeholders involved in the development of tourism in Tanjungpinang based on the Pentahelix concept?

b) What is the role of the stakeholders in the development of tourism in Tanjungpinang based on the Pentahelix concept?

c) Aspects of what is inhibiting the role of stakeholders in the development of tourism in Tanjungpinang?

\section{Methodology}

This research is a descriptive qualitative research type. The data source consisted of primary data obtained from direct research informants. Determination of informants using purposive and snowball techniques. This research has twenty-seven informants. Then the data source secondary obtained through the documentation and source else who can provide information related to the focus of research. Collecting data is done with interviews and documentation online. The data analysis process adopted the thinking of Miles and Huberman [3], namely; data condensation, data presentation, and drawing conclusions. Quality in this research, referring to the qualitative research must meet the validity of the data. 


\section{Results and Discussion}

\subsection{Identification of Tourism Development Stakeholders in Tanjungpinang}

a) Academics

Raja Haji College of Social and Political Sciences (Stisipol), Raja Ali Haji Maritime University (UMRAH) and Gajah Mada University (UGM).

b) Business

Association of Indonesian Hotels and Restaurants (PHRI) Tanjungpinang, Association of the Indonesian Tours and Travel Agencies (ASITA) Tanjungpinang, Association of Indonesian Tour Guides (HPI) Tanjungpinang, Association of Home Culinary, Bank Indonesia, PT. Pelabuhan Indonesia I (Pelindo 1) and Al Ahmadi Entrepreneurship Center Batam.

c) Government

Tanjungpinang City Culture And Tourism Office, Tanjungpinang City Trade And Industry Service, Tanjungpinang City Cooperative And UMKM Office, Tanjungpinang City Health Service, Tanjungpinang City Transportation Service, Tanjungpinang City public Works And Spatial Planning Office, Tanjungpinang City Planning, Research And Development Agency, Unit The Civil Service Police And Fire Management Of Tanjungpinang City, The Riau Islands Province Transportation Service, The Ministry Of Religion The Riau Islands Province Regional Office, The Regional Representative Council Of Tanjungpinang City.

d) Community

The Tourism Awareness Group (Pokdarwis), the Riau Islands Indonesian Ulema Council (MUI), the Indonesian Ulema Council (LPPOM MUI) Research Institute for Food, Medicine and Cosmetics, the Riau Islands, the Malay Customary Institution (LAM) of the Riau Islands Province, the Indera Sakti Foundation, the Foundation Action to Build the Country, Blogger Community, Photography Community, and the Generation of Indonesian Enchantment (Genpi) Tanjungpinang.

e) Mass media

Radio Republik Indonesia (RRI) Tanjungpinang, Batam Pos, Tanjungpinang Pos, Tribun Batam, Antara Kepri, Metro Kepri, TV TPI, and Kepri Cyber School (KCS) TV.

\subsection{The Role of Tourism Development Stakeholder in Tanjungpinang Based on the Pentahelix Concept}

a) Academics

Based on the results of interviews with academic informants, it was found that the role of academics was still not optimal in tourism development in Tanjungpinang. The Tanjungpinang City Government through the Culture and Tourism Office does not really involve the participation of academics in the regions to contribute in planning or implementing tourism development policies. 
Gadjah Mada University (UGM) is one of the universities that plays a role in developing tourism on Penyengat Island. Through the Community Empowerment Learning Real Work Lecture (KKN-PPM) in 2018, 25 UGM students carried out the Penyengat Island Citizen Declaration at the Penyengat Village Hall with the theme "Penyengat Kite Village, Penyengat Kite heritage".

Higher education is a very strategic institution in encouraging the acceleration of community development [4]. With a number of advantages such as human resources, wellestablished institutional tools, and the ability to make research and studies, universities can act as agents of development, which help support regional development activities as well as become agents of control for every policy and process. existing management.

b) Business

PHRI Tanjungpinang as the coordinator of hotel and restaurant entrepreneurs in Tanjungpinang, provides input and ideas to the local government regarding service standards applied in hotels and restaurants. ASITA Tanjungpinang, which consists of tour and travel entrepreneurs in Tanjungpinang, provides input to the government regarding Tanjungpinang tourism. Improvement of the packaging quality of Tanjungpinang tourism products must be done so that the tour packages sold by tour and travel parties are in great demand by tourists. HPI Tanjungpinang conveyed input to the local government regarding the needs of tourists during their tours that have not been accommodated, as well as input on developing the human resource capacity of guides in Tanjungpinang. Furthermore, the role of the Home Culinary Association as a target group is to coordinate culinary entrepreneurs in producing halal culinary for visiting Muslim tourists, as well as involvement in tourism events.

Al Ahmadi Entrepreneurship Center plays a role in organizing the Road to Fesyar (Sharia Economic Festival) Penyengat Island Festival at Syawal Serantau in 2017. Bank Indonesia Riau Islands contributed in the form of sponsorship assistance for the procurement of life jackets for the boats crossing Penyengat Island. Tourism development Tanjungpinang realized in the form of signing the $\mathrm{MoU}$ on the Management and Optimization of ObjectBased Tourism Community Empowerment between PT Pelabuhan Indonesia 1 (Persero) or Pelindo 1 with the City of Tanjungpinang.

The involvement of the private sector in the development of halal tourism destinations on Penyengat Island is in line with Olovsson and Berendji [5] who argues that it is very important to include the private sector when shaping the brand values of a city. Only applying a public sector approach can slow down and render decision making ineffective.

c) Government

The Mayor of Tanjungpinang as the executive has a role in proposing a draft Regional Regulation and establishing regional regulations that have received joint approval from the DPRD. The DPRD of Tanjungpinang City as the legislative party carries out the functions of legislation, budgeting and supervision, and has a role in submitting proposals for draft Regional Regulations and discussing with the Mayor whether or not they approve the proposed draft Regional Regulation.

Brokaj [6] states that local governments must provide an enabling environment and encourage the private sector, local communities, tourists and her stakeholders to respond to tourism problems in a sustainable manner. This can be achieved by establishing and implementing a series of policies for tourism development and management, co-developed with other parties. 
The Planning, Research and Development Agency (Barenlitbang) of Tanjungpinang City acts as a policy creator in developing tourism destinations. Tanjungpinang City Barenlitbang plays a role in its capacity regarding tourism development planning arranged in the Tanjungpinang City Strategic Plan. So that in the formulation of policies, the Barenlitbang of Tanjungpinang City has an important role in it. Department of Culture and Tourism Tanjungpinang role as policy creator with a contribution as aleading sector in the development of tourism development in Tanjungpinang which has the concept and strategy of tourism development. The Department of Culture and Tourism of Tanjungpinang City in carrying out its role as the implementer of the policy for developing halal tourism destinations on Penyengat Island through improving tourist destinations by building tourism supporting infrastructure and providing information on tourist attractions through tourism marketing activities through tourism events or digital marketing.

The Tanjungpinang City Transportation Office and the Riau Islands Province Transportation Office are stakeholders who act as facilitators in providing access. The Public Works and Spatial Planning Office of Tanjungpinang City plays a role in building facilities and infrastructure in tourism development. The role of the Tanjungpinang City Public Works and Spatial Planning Agency can be seen from the provision of clean water and the preparation of the Penyengat Island Building and Environmental Planning (RTBL). With regard to safety standards, benefits and product quality, the food and beverage available must have a certificate from the BPOM which can be processed through the Tanjungpinang City Health Office. The Tanjungpinang City Trade and Industry Office, in collaboration with the Ministry of Religion and LPPOM MUI, has an annual work program to facilitate the halal certificate process for MSMEs. Department of Cooperatives and SMEs Tanjungpinang role in SMEs building from coaching aspect of management, market development and facilitation of SME products business capital. The role of the Civil Service Police and Fire Management Unit of Tanjungpinang City is to enforce the local regulation on order, maintain public security and order, and protect vital tourism objects.

The Halal Product Guarantee Agency forms representatives in the regions, one of which is in the form of a Task Force under the Ministry of Religion of the Riau Islands Regional Office. The task force under the Ministry of Religion of the Riau Islands Regional Office acts as a facilitator for issuing halal certificates for food and beverage products in tourism development in Tanjungpinang.

\section{d) Community}

Pokdarwis as a local tourism development community has made marketing efforts through Facebook, Instagram and YouTube, one of which is Pokdarwis Pulau Penyengat. Marketing via YouTube was only carried out in 2018 by uploading 1 video on the Pokdarwis Island Penyengat YouTube account. The management of Penyengat Island tour packages is left to Pokdarwis Penyengat Island, and the cost of the tour packages as a source of revenue for Pokdarwis Penyengat Island budget. Pokdarwis also conducted socialization about Sapta Pesona to the public. The Aksi Bangun Negeri Foundation contributed to the development of Tanjungpinang tourism by preserving Malay cultural values by encouraging the movement to turn Penyengat Island into a world heritage. The Cultural Foundation of Indera Sakti Penyengat Island has contributed to the preservation of Malay culture in terms of saving ancient Riau manuscripts, especially those written or printed on Penyengat Island. Another mission is as a center for cultural information, book authorship, and data services (for researchers). The Riau Archipelago Traditional Malay Institute (LAM) contributed to the development of Tanjungpinang tourism through input and ideas regarding Tanjungpinang 
tourism that must be built following the rules of Malay customs, especially in trade and community ethics including language speech, clothing, and communication patterns.

Djakfar [7] states that Mahathir Mohammad once proposed three tips for advancing halal tourism based on his observations in his own country, namely promoting and maintaining Islamic values and local wisdom; adopt the good things of the systems and standards dominated by Western civilization; and running the concept and market-oriented.

The role of LPPOM MUI is to check the halal quality of a product. Meanwhile, the MUI is in charge of giving a fatwa on the halal of a product. Genpi Tanjungpinang conducts promotions for tourism events. Genpi has also contributed to creating new tourist destinations on Penyengat Island, namely the Heritage of Penyengat Island. In addition, Genpi Tanjungpinang together with the Culture and Tourism Office of the City of Tanjungpinang in collaboration with the Travel Association and Malay Association in Singapore to promote cultural and religious tourism on Penyengat Island, which targets young people from the Malay ethnic group in Singapore. The photography community especially plays a big role in promoting Tanjungpinang tourism through the results of the photos on social media pages. The blogger community contributes through deafness and posts on blogs related to Penyengat Island, for example regarding lodging on Penyengat Island, tourist destinations, and uploading photos of interesting spots on Penyengat Island.

e) Mass Media

The involvement of the mass media in the development of Tanjungpinang tourism is very helpful in conveying information to the community about tourism in Tanjungpinang. As an accelerator that plays a role in accelerating the timing of policy implementation, the mass media disseminate knowledge and information to the public and accelerate the process of socializing the implementation of tourism development policies in Tanjungpinang.

RRI conducted an interactive dialogue in 2019 with the topic "Tanjungpinang Halal Tourism Destinations". Other mass media involved in tourism development in Tanjungpinang are Batam Pos, Tanjungpinang Pos, Tribun Batam, Antara Kepri, Metro Kepri, TPI TV, and Kepri Cyber School (KCS) TV. Batam Pos through its online page batampos.co.id uploaded news about Penyengat Island as a halal tourist destination through the 2017 Penyengat Syawal Serantau Island Festival, Tanjungpinang Pos reported the same thing regarding the implementation of the 2017 Syawal Serantau Penyengat Island Festival. Batam Tribune, Between Riau Islands and Metro Kepri reported about the implementation of the 2020 Penyengat Island Festival which is planned to be in February 2020. TPI TV uploaded its coverage of the 2019 Penyengat Island Festival on its YouTube channel. Likewise, KCS TV, which is under the responsibility of the Riau Islands Provincial Education Office, plays an active role in broadcasting information about the development of Penyengat Island tourism, in the form of coverage of Penyengat Island tourism events which certainly supports tourism development in Tanjungpinang.

The tourism industry uses the mass media to inform the public about tourism offers. So, through the media, communication is projected for a larger audience and a fairly wide geographical area. So, advances in technology and mass media are very helpful for the expansion and development of tourism optimally. 


\subsection{Aspects That Inhibit Tourism Development in Tanjungpinang}

\section{a) Trust}

Trust is one of the inhibiting factors in cooperative relations between stakeholder in developing tourism destinations. There is the lack of trust in tourism development partnerships. Stakeholder involved in developing tourism destinations carry out their roles in accordance with their duties and functions. However, there are several stakeholders who have not been able to carry out their roles optimally. This results in a lack of trust in the cooperative relationship between stakeholders. The absence of clear commands and directions regarding the development of halal tourism destinations has led to a lack of trust in the tourism activist community towards the Tanjungpinang City Culture and Tourism Office. This lack of trust is manifested in the actions of the tourism activist communities who carry out their respective activities according to their institutions, so that there is no synergy of activities coordinated by the leading sector. Waayers [8] research emphasizes that successful collaboration depends on building partnerships and trust, recognizing interdependence, generating a common vision and goals and commitment among stakeholders in a structured process.

The attitude of lack of trust in the relationship of cooperation stakeholders the development of halal tourism destinations Biting Island also caused by the transfer of authority from one stakeholder to stakeholders other new, so it takes an adjustment procedure of activities by stakeholders new. This is like what happened in the facilitation of free halal certificates for UMKM players from the Tanjungpinang City Industry and Trade Office in collaboration with the Riau Islands LPPOM MUI. With the issuance of Law Number 33 of 2014 concerning Halal Product Guarantee, the authority to issue halal certificates that was originally at LPPOM MUI moved to BPJPH under the Ministry of Religion. The lack of trust of the Tanjungpinang City Industry and Trade Office in the performance of BPJPH, which is considered not optimal in exercising its new authority, has made it one of the inhibiting factors in cooperation between the stakeholders involved.

\section{b) Policy}

The management of Penyengat Island as a leading cultural tourism destination has been regulated in the Regional Regulation of the City of Tanjungpinang Number 8 of 2018 concerning Management of Penyengat Island Cultural Tourism. However, the policy that regulates the development of halal tourism in Tanjungpinang City is not yet available, as was the result of the interview given by the informant above. In the absence of policies in the form of regulations, the direction of tourism development is still unclear and measurable. This is certainly an obstacle in the process of developing halal tourist destinations. The unavailability of regulations on the development of halal tourism in Tanjungpinang City certainly creates uncertainty for tourism industry players to apply the concept of halal tourism. The absence of a legal umbrella is one of the obstacles in the collaboration process between relevant stakeholders.

Judisseno [9] states that the government must establish a tourism development policy framework so that the private sector has a foothold and foundation if they want to participate in tourism development. Government involvement is more in the aspect of policy making that encourages growth and to the maximum extent possible to remove various bureaucratic obstacles. 


\section{Conclusion}

There are 38 stakeholders involved in tourism development in Tanjungpinang with a Pentahelix model consisting of academics, business, government, community, and mass media. The role of academics is still not optimal in tourism development in Tanjungpinang. The Tanjungpinang City Government through the Culture and Tourism Office does not really involve the participation of academics in the regions to contribute in planning or implementing tourism development policies. Private parties that play a role in tourism development in Tanjungpinang are PHRI, ASITA, HPI, Al Ahmadi Entrepreneurship Center, Bank Indonesia Riau Islands and PT Pelabuhan Indonesia 1 (Persero). The government plays a role in tourism development in Tanjungpinang in accordance with the main duties and functions of each government agency. Communities that take on the role are Pokdarwis, Yayasan Aksi Bangun Negeri, Indera Sakti Penyengat Island Cultural Foundation, Riau Islands Customary Institution (LAM), LPPOM MUI, MUI, Genpi Tanjungpinang. While the mass media that play a role are RRI Tanjungpinang, Batam Pos, Tanjungpinang Pos, Tribun Batam, Antara Kepri, Metro Kepri, TPI TV, and Kepri Cyber School (KCS) TV. Aspects Obstructing Tourism Development in Tanjungpinang are aspects of trust and aspects of policy.

\section{References}

[1] I. Nugroho, F. H. Pramukanto, P. D. Negara, W. Purnomowati, and W. Wulandari, "Promoting the rural development through the ecotourism activities in Indonesia," Am. J. Tour. Manag., vol. 5, no. 1, pp. 9-18, 2016.

[2] U. Susanti, "Fungsi Dinas Kebudayaan dan Pariwisata Kota Tanjungpinang dalam Usaha Melestarikan Cagar."

[3] M. B. Miles, A. M. Huberman, M. A. Huberman, and M. Huberman, Qualitative data analysis: An expanded sourcebook. sage, 1994.

[4] R. H. Magnadi and F. Indriani, "Peran Perguruan Tinggi dalam Membangun 'City Branding' yang Berkelanjutan: Sebuah Upaya untuk Mendorong Pertumbuhan Perekonomian Daerah," Pros. SNaPP Sos. Ekon. dan Hum., vol. 2, no. 1, pp. 281-290, 2011.

[5] C. Olovsson and D. Berendji, "Umeå. Wants more.: A coordination perspective on how key stakeholders develop placebrand identity." 2012.

[6] R. Brokaj, "Local Governments role in the sustainable tourism development of a destination," Eur. Sci. J., vol. 10, no. 31, 2014.

[7] M. Djakfar, Pariwisata halal perspektif multidimensi: peta jalan menuju pengembangan akademik \& industri halal di Indonesia. UIN-maliki Press, 2017.

[8] D. Waayers, D. Lee, and D. Newsome, "Exploring the nature of stakeholder collaboration: A case study of marine turtle tourism in the Ningaloo region, Western Australia," Curr. Issues Tour., vol. 15, no. 7, pp. 673-692, 2012.

[9] R. K. Judisseno, Aktivitas dan Kompleksitas Kepariwisataan. Gramedia Pustaka Utama, 2017. 